\title{
Summary of a 12-Year Experiment in the Use of 50\% RME Fuel Mixture in Heavy Trucks and Light Vehicles
}

\author{
P. Gateau \\ 21, rue de la poterie, 44640 Saint-Jean-de-Boiseau - France \\ e-mail: gateau.paul@wanadoo.fr
}

Résumé - Synthèse de 12 années d'utilisation comme carburant d'un mélange à $50 \%$ d'EMC sur poids lourds et véhicules légers - Entre 1993 et 2005, une expérimentation portant sur l'utilisation d'un mélange de gazole avec $50 \%$ d'EMC (Esters méthyliques d'huile de colza) a été réalisée à la coopérative agricole Champagne Céréales. Vingt poids lourds allant des réglages EURO 0 à EURO 3, dix véhicules légers équipés de moteurs à préchambre et quatre véhicules légers (406 et C5) équipés de moteur à « rail commun » et de FAP (filtre à particules) ont été suivis. La moitié de ces véhicules étaient alimentés à l'EMC50 et accompagnés de véhicules témoins identiques roulant au gazole et réalisant des services similaires.

Les poids lourds ont roulé à l'EMC50 entre $230000 \mathrm{~km}$ et $530000 \mathrm{~km}$. La 406 a dépassé $230000 \mathrm{~km}$ et la C5 $190000 \mathrm{~km}$. Sur douze années, les consommations ont été relevées et les lubrifiants ont été analysés. Des systèmes d'injection ont été expertisés et dix moteurs de poids lourds ont été démontés pour la mesure de l'usure et des dépôts. L'EMC n'a pas été la cause du moindre problème. Son incidence sur la consommation répond à l'écart de $\mathrm{PCI}$ (pouvoir calorifique inférieur).

Certains véhicules ont été sujets à de la dilution du lubrifiant et ce phénomène a été accentué par l'EMC. La baisse de viscosité n'a pas occasionné d'augmentation d'usure. Les moteurs cotés n'ont pas montré la présence de dépôts dans les segmentations ni les carters. L'emploi d'EMC a même entraîné une réduction de l'usure sur certains poids lourds en abaissant le taux de matières charbonneuses dans le lubrifiant.

\footnotetext{
Abstract - Summary of a 12-Year Experiment in the Use of 50\% RME Fuel Mixture in Heavy Trucks and Light Vehicles - Experiments on the use of a 50\% RME (Rapeseed Oil Methyl Ester) fuel mixture were conducted at the agricultural cooperative "Champagne Céréales", over the period 19932005. The study was carried out on twenty heavy trucks from EURO 0 to EURO 3 standards, ten light vehicles with indirect injection engines and four light vehicles ("Peugeot 406" and "Citroën C5") equipped with "common rail" engine and with DPF (diesel particulate filter). Half of these vehicles used RME50 fuel and performed the same services along with another group of reference vehicles running on standard diesel fuel. The mileage run on RME50 by heavy trucks ranged between 230000 and $530000 \mathrm{~km}$.
} 
"406" sedan mileage exceeded $230000 \mathrm{~km}$ and "C5" $190000 \mathrm{~km}$. Consumption was recorded and lubricants were analysed over the twelve-year period. Injection systems were examined and ten heavy truck engines were disassembled for wear and deposits assessment. The use of RME resulted in no notable incident, and its effect on consumption was according to LHV (lower heating value) variation.

Lubricant dilution was observed on some vehicles, and this phenomenon was reinforced by the use of $R M E$. The lower viscosity level did not cause any increase of wear. The assessed engines showed no sign of deposits in rings and crankcases. On the other hand, the use of RME reduced wear on certain heavy trucks due to lower soot contents in the lubricant.

\section{INTRODUCTION}

Vegetable oil methyl or ethyl esters have a positive impact on carbon dioxide emissions and are becoming competitive with high petroleum prices. The first interest to use RME as a fuel was to provide new massive non-food markets for agriculture products [1]. So RME have been experimented in engines for long time [2].

The agricultural cooperative "Champagne Céréales" located at Reims and IFP tested with success the use of a $20 \%$ fuel mixture on a very mixed group of vehicles between 1988 and 1990. The cooperative, with its four hundred vehicles in operation and engine repair shop, offered a good opportunity to start a test over a long period/high mileage, in order to come up with hard comparative data. It was then launched in 1993 and lasted until 2005.

The 1993-2005 study included heavy trucks meeting the EURO 0 to EURO 3 standards, light vehicles with indirect injection engines and recent cars equipped with common rail injection system and DPF.

Test vehicles were inspected regularly over the twelveyear period, with carried tons, mileage and consumption recorded, and the lubricant analysed at defined intervals. This Report summarizes the results of this twelve-year experiment.

\section{FUEL}

The fuel used was a mixture of diesel fuel and RME. French fleets use a 30\% RME ratio (RME30) [3, 4] but in this experimental program, RME50 was selected in 1993 and maintained over the full test period: its LHV is about $4 \%$ lower than that of standard diesel fuel.

Undistilled RME [5, 6] meeting Standard EN 14214 [7] requirements was supplied over the 12-year period by the Compiègne (France) unit of the Diester Industrie Company.

RME and diesel fuel are perfectly miscible. Mixtures were made periodically in a $110 \mathrm{~m}^{3}$ tank with commercial diesel fuel used in reference vehicles and the other vehicles of the cooperative. The storage tanks of pure RME, diesel fuel and RME50 were cleaned in 1993 and 1999.
The mixtures used by "Champagne Céréales" never received additives other than the ones included in the diesel fuel purchased.

\section{TESTS ON HEAVY TRUCKS}

\subsection{The Experimental Fleets}

Each test vehicle running on RME50 fuel was associated with an identical reference vehicle carrying out a similar service, so twenty vehicles (Table 1) were investigated: 18 trailer-trucks with a permissible total laden weight (GVWR) of 40 metric tons and powers ranging between 243 and $283 \mathrm{~kW}$ and two vehicles of $192 \mathrm{~kW}$ with a 19-ton GVWR. Vehicles 6, T6, 10 and T10 were equipped with pump injectors. Vehicle pairs 1 to 5 met EURO 1 standard and previous. Vehicle pairs 6 to 9 met EURO 2 standard and vehicle pair 10 met EURO 3.

TABLE 1

Experimental trucks fleet

\begin{tabular}{c|c|c}
\hline Vehicles & Models & Standards \\
\hline $1, \mathrm{~T} 1,2$ \& T2 & SCANIA 113 & EURO 0-1 \\
\hline $3 \& \mathrm{~T} 3$ & VOLVO F10 & EURO 0 \\
\hline $4 \& \mathrm{~T} 4$ & VOLVO F12 & EURO 1 \\
\hline $5 \& \mathrm{~T} 5$ & RVI R330 & EURO 0 \\
\hline $6 \& \mathrm{~T} 6$ & VOLVO FH12 & EURO 2 \\
\hline $7 \& \mathrm{~T} 7$ & RVI P260D & EURO 2 \\
\hline $8, \mathrm{~T} 8,9 \& \mathrm{~T} 9$ & RVI P385R & EURO 2 \\
\hline $10 \& \mathrm{~T} 10$ & SCANIA 114 & EURO 3
\end{tabular}

\subsection{General Behaviour of Trucks}

Dates and engine mileages are reported on Table 2. Six vehicles have covered more than $440000 \mathrm{~km}$ with RME50.

The vehicles were used for the services of the agricultural cooperative, which are not only road transport, but also driving ancillary equipment (tailgate, etc.) while the vehicles were stationary. 
Data on mileage run, consumption (badge used to fill the tank), drivers' working hours and tons carried were recorded in a precise manner, and averages calculated. Services provided by the vehicles could then be compared on such variables as vehicle load (ratio of mileage run and tons carried), journey speed (journey distance divided by journey time). Table 3 displays summary results with average annual values (n values) available and their standard deviation $(n-1)$. Except for pair 10, it can be noted that the difference of load and speed is not significant enough to affect the comparison of behaviours in favour of RME50. Vehicle T10 is more often affected to road transport than vehicle 10.

Annual consumption variations for each vehicle and differences between the test vehicle and its reference counterpart were explained by dispersions in drivers' habits. However, drivers and services differences were smoothed over the years and the average consumption of all diesel fuel vehicles is lower by $3.3 \%$ than that of all RME50 vehicles. It is consistent with the LHV (lower heating value) volume variation of the fuels.

No mechanical incident was reported for the ten vehicles running on RME50 except a change of the water pump on vehicle 8 . The reference vehicles experienced more problems.

Trucks were parked at night in unsheltered locations, with no protection from the wind, and tanks had no cover. No problem for starting engines in the winter was reported despite low temperatures (below $-12^{\circ} \mathrm{C}$ ) recorded during several winters.
TABLE 2

Trucks mileage

\begin{tabular}{|c|c|c|c|c|c|}
\hline & \multicolumn{2}{|c|}{$\begin{array}{c}\text { Start of } \\
\text { experimentation }\end{array}$} & \multicolumn{2}{|c|}{$\begin{array}{c}\text { End of } \\
\text { experimentation }\end{array}$} & \multirow[t]{2}{*}{$\begin{array}{l}\text { Experimental } \\
\text { mileage }(\mathrm{km})\end{array}$} \\
\hline & Date & $\mathrm{km}$ & Date & $\mathrm{km}$ & \\
\hline 1 & 1993 & 5170 & 1998 & 320467 & 315297 \\
\hline$T 1$ & 1993 & 13520 & 1998 & 299777 & 286257 \\
\hline 2 & 1993 & 66115 & 1999 & 508016 & 441901 \\
\hline$T 2$ & 1993 & 67501 & 2000 & 521114 & 453613 \\
\hline 3 & 1993 & 169023 & 2000 & 664160 & 495137 \\
\hline$T 3$ & 1993 & 173908 & 2000 & 658692 & 484784 \\
\hline 4 & 1993 & 7525 & 1998 & 304277 & 296752 \\
\hline$T 4$ & 1993 & 18300 & 1996 & 236600 & 218300 \\
\hline 5 & 1993 & 196995 & 1997 & 510743 & 313748 \\
\hline$T 5$ & 1993 & 186740 & 1996 & 433233 & 246493 \\
\hline 6 & 1998 & 87150 & 2005 & 577045 & 489895 \\
\hline T6 & 1998 & 90176 & 2005 & 568492 & 478316 \\
\hline 7 & 1998 & 103702 & 2004 & 559293 & 455591 \\
\hline$T 7$ & 1998 & 92408 & 2004 & 534762 & 442354 \\
\hline 8 & 1998 & 17347 & 2005 & 547911 & 530564 \\
\hline$T 8$ & 1998 & 23630 & 2005 & 541509 & 517879 \\
\hline 9 & 1998 & 18953 & 2005 & 538484 & 519531 \\
\hline$T 9$ & 1998 & 21221 & 2005 & 530126 & 508905 \\
\hline 10 & 2002 & 0 & 2005 & 230664 & 230664 \\
\hline T10 & 2002 & 0 & 2005 & 275025 & 275025 \\
\hline
\end{tabular}

TABLE 3

Average annual values for fuel consumptions and loads

\begin{tabular}{|c|c|c|c|c|c|c|c|}
\hline \multirow[b]{2}{*}{ Vehicle } & \multicolumn{2}{|c|}{ consumption ( 1/100 km) } & \multicolumn{2}{|c|}{ load $(\mathrm{km} / \mathrm{t})$} & \multicolumn{2}{|c|}{ journey speed (km/h) } & \multirow[b]{2}{*}{ years } \\
\hline & mean & standard deviation & mean & standard deviation & mean & standard deviation & \\
\hline 2 & 43.6 & & 2.7 & & 29.6 & & $98-99$ \\
\hline$T 2$ & 40.7 & & 2.1 & & 27.9 & & $98-99$ \\
\hline 3 & 40.5 & & 2.7 & & 28.7 & & $98-99$ \\
\hline$T 3$ & 40.3 & & 2.6 & & 29.3 & & $98-99$ \\
\hline 6 & 43.0 & 2.2 & 3.3 & 1.8 & 29.4 & 0.7 & $98-04$ \\
\hline T6 & 43.0 & 1.5 & 2.6 & 0.3 & 29.4 & 1.2 & $98-04$ \\
\hline 7 & 24.4 & 0.7 & 43.7 & 3.9 & 34.2 & 1.4 & $98-03$ \\
\hline$T 7$ & 24.5 & 0.6 & 43.5 & 5.1 & 33.7 & 1.1 & $98-03$ \\
\hline 8 & 46.3 & 2.0 & 2.8 & 0.1 & 31.4 & 1.2 & $98-04$ \\
\hline$T 8$ & 44.5 & 1.5 & 2.7 & 0.2 & 31.3 & 1.4 & $98-04$ \\
\hline 9 & 43.8 & 1.4 & 2.7 & 0.4 & 30.8 & 2.9 & 98-04 \\
\hline$T 9$ & 41.8 & 1.4 & 2.7 & 0.3 & 32.3 & 0.8 & $98-04$ \\
\hline 10 & 42.9 & 0.7 & 2.4 & 0.1 & 25.8 & 1.6 & 02-04 \\
\hline T10 & 40.3 & 1.4 & 3.5 & 0.2 & 31.2 & 1.5 & $02-04$ \\
\hline
\end{tabular}


TABLE 4

Trucks lubricants analysis (average values)

\begin{tabular}{|c|c|c|c|c|c|c|c|c|c|}
\hline & $\mathrm{nb}$ of oil changes & Fe ppm & st. deviat. Fe & $\mathrm{Pb}$ ppm & $\mathrm{Cu}$ ppm & Soot $\%$ & Visc. $100^{\circ} \mathrm{C} \mathrm{cSt}$ & Visc. $40^{\circ} \mathrm{C} \mathrm{cSt}$ & B.N. mg KOH \\
\hline 1 & 11 & 26 & 7 & 9 & 7 & 0.39 & 12.2 & 82.3 & 12.2 \\
\hline$T 1$ & 10 & 42 & 6 & 10 & 6 & 1.13 & 13.4 & 94.7 & 11.9 \\
\hline 2 & 15 & 26 & 6 & 10 & 3 & 0.40 & 12.5 & 86.2 & 12.8 \\
\hline$T 2$ & 16 & 35 & 12 & 10 & 6 & 0.53 & 13.4 & 96.2 & 13.0 \\
\hline 3 & 17 & 53 & 9 & 5 & 4 & 1.67 & 13.4 & 95.4 & 11.6 \\
\hline$T 3$ & 17 & 53 & 13 & 14 & 7 & 1.85 & 13.7 & 98.7 & 10.6 \\
\hline 4 & 10 & 35 & 8 & 9 & 6 & 0.49 & 13.7 & 95.6 & 12.7 \\
\hline$T 4$ & 6 & 35 & 7 & 5 & 5 & 0.47 & 13.0 & 95.4 & 12.3 \\
\hline 5 & 10 & 65 & 12 & 20 & 10 & 0.91 & 11.5 & 73.1 & 10.0 \\
\hline$T 5$ & 8 & 78 & 28 & 18 & 6 & 1.33 & 14.7 & 109.6 & 11.3 \\
\hline 6 & 16 & 32 & 6 & 17 & 3 & 0.97 & 12.0 & 82.3 & 11.0 \\
\hline T6 & 16 & 40 & 12 & 6 & 3 & 1.34 & 13.5 & 98.0 & 11.8 \\
\hline 7 & 15 & 10 & 3 & 4 & 7 & 0.27 & 11.3 & 75.2 & 12.9 \\
\hline$T 7$ & 12 & 14 & 8 & 3 & 6 & 0.31 & 12.3 & 86.6 & 12.9 \\
\hline 8 & 18 & 25 & 12 & 7 & 21 & 0.83 & 12.3 & 85.0 & 12.2 \\
\hline$T 8$ & 18 & 20 & 6 & 8 & 36 & 0.66 & 12.9 & 91.9 & 13.1 \\
\hline 9 & 17 & 16 & 4 & 5 & 15 & 0.39 & 12.1 & 83.4 & 11.9 \\
\hline$T 9$ & 19 & 16 & 4 & 7 & 84 & 0.60 & 12.6 & 89.4 & 12.1 \\
\hline 10 & 6 & 18 & 6 & 8 & 39 & 0.35 & 10.8 & 66.0 & 10.3 \\
\hline$T 10$ & 7 & 17 & 7 & 5 & 64 & 0.47 & 10.5 & 66.8 & 8.5 \\
\hline
\end{tabular}

\subsection{Heavy Truck Lubricant Analyses}

Lubricants used in the test vehicles were selected to represent a standard quality product of the lubricants' market.

From 1993 to 1998, lubricant was oil Elf XT 2580 of quality grade D5 CCMC; it was then replaced by oil Elf Trophy R and, in 2002, by oil Total Rubia TIR Max.

They have viscosities of about 105 and $15 \mathrm{cSt}$ respectively at $40^{\circ} \mathrm{C}$ and $100^{\circ} \mathrm{C}$ and are of SAE grade $15 \mathrm{~W}-40$.

All lubricants were systematically analyzed at oil changes with oil change interval always kept to $30000 \mathrm{~km}$. Attention was given to the following variables:

- Contents of iron, lead, copper, tin, chromium, aluminium, nickel and silicon;

- Water content, and antifreeze content;

- Dilution ratio determined by the flash point;

- Soot content;

- Viscosities at $100^{\circ} \mathrm{C}$ and $40^{\circ} \mathrm{C}$;

- Basic number (BN), acid value (AN).

Silicon comes both from additives $(15 \mathrm{ppm}$ in oil Elf XT 2580) contained in the lubricant and from airborne dusts sucked in by the engine. Values always remained low for all the vehicles, demonstrating air filters' adequate maintenance and quality. So differences of wear can't be attributed to dusts.

Acid number remained mainly between 3 and $4 \mathrm{~g}$ of $\mathrm{KOH}$ per $\mathrm{kg}$ of lubricant for all the vehicles. There is also no significant effect of the fuel on the mean values of basic number (Table 4).

The flash point dilution method is not well suited to RME content. On analysis bulletins, dilution is only significant when viscosity falls below $80 \mathrm{cSt}$. In theory, the viscosity of a mixture could be estimated according to a logarithmic law [8]. For example, a 3\% adjunction of pure RME decreases the $40^{\circ} \mathrm{C}$ viscosity of a new lubricant from $100 \mathrm{cSt}$ to $90 \mathrm{cSt}$. The reported viscosity values show the importance of dilution but give only a qualitative information: the calculation of fuel content from viscosity is inapplicable to a used lubricant, as the degradation of the product should also be taken into account.

Table 4 displays the results of the study. The values are averages of all the analysis at oil changes.

On the same vehicle, the variations of iron contents observed on the successive oil changes follow a standard pattern with no large differences. The average value is a 
significant variable that permits to compare wear among vehicles of the same type. However, for lead and copper, several average contents incorporate temporary high values due both to break-in period and bearing problems connected with leaks of coolant into the lubricant. The average values of these two elements are reported but shall then not be compared. Tin, chromium, aluminium and nickel contents are identical for RME50 and reference vehicles, so they are not reported.

When RME50 fuel is used, a fall of lubricant viscosity always occurs, except on vehicles 3 and 4 . With the only exception of vehicle pair 8 , the content of wear metals is always lower or equal for RME50 vehicles. Therefore, it can be said that the fall of viscosity never caused an increase of wear metals. The fall of iron contents is indeed correlated with a fall of the soot content, and RME has a well-known effect to reduce smoke emissions [3, 4]. Pair 8 behaviour is consistent since soot content is slightly greater for the RME50 vehicle.

For pair 10, the fall of viscosity is significant and occurs on both vehicles whatever the fuel. It is due to normal microleaks of the pump on each injector. Copper percentages are high on analysis reports and can be attributed to a heat exchanger.

\subsection{Effect of Lubricant Dilution}

Dilution observed first on vehicle 5 was significant. The presence of RME in the lubricant was confirmed by infrared spectra.

In other experiments with buses, a corrosion of the lead coating of tanks had been observed. So it was suspected that the presence of RME in the lubricant could corrode the bearings.

Hence it was decided to analyse the lubricant every $5000 \mathrm{~km}$ over two oil change intervals between 253000 and $350000 \mathrm{~km}$. For comparison purposes, vehicle T5 lubricant was analysed between 293000 and $330000 \mathrm{~km}$ but only on one oil change interval.

The viscosity trend is very different for these two vehicles (Fig. 1).

The iron content (Fig. 2) increases definitely more for T5. The higher wear was explained later: a strong degree of bore polishing was observed at the $433000 \mathrm{~km}$ mileage. It explains also the viscosity rise.

In spite of these strong differences, the lead and copper contents changes (Fig. 3) are similar for both vehicles. For the three oil change intervals, the BN curves are also similar and not presented here. So, with or without RME in the lubricant, there is no difference in bearings wear.

The presence of a sudden rise of lead and copper in oil is sometimes attributed to RME by error. Attention should be given to antifreeze content in the lubricant, water being

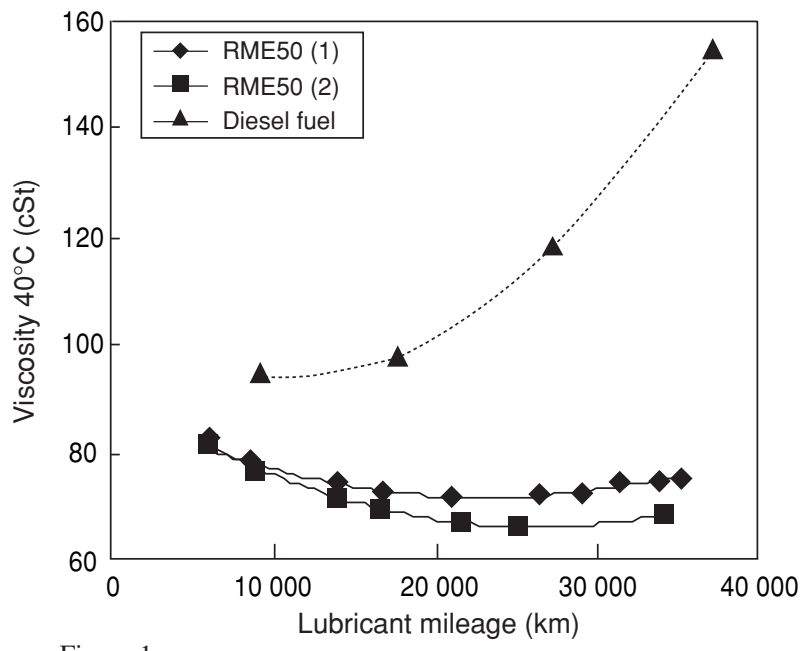

Figure 1

Lubricant viscosity evolution.

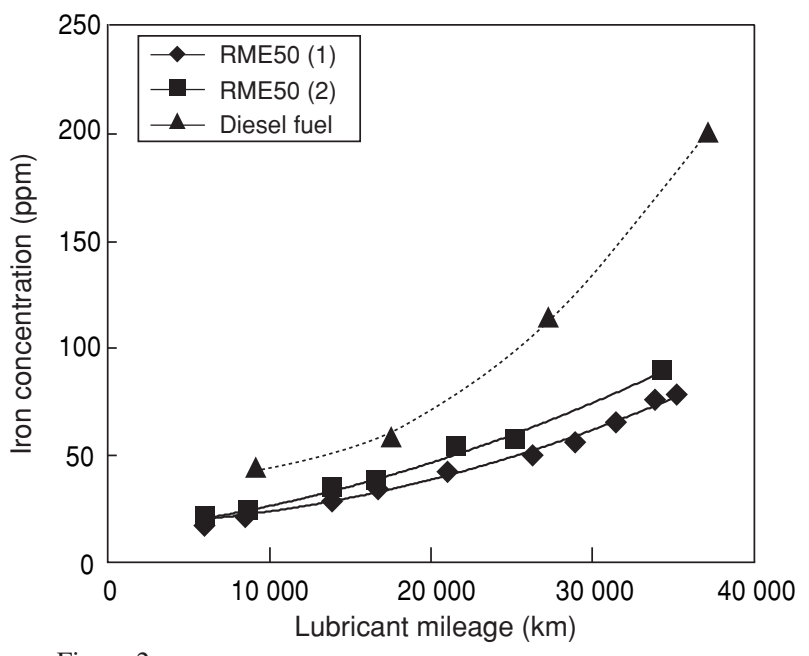

Figure 2

Iron evolution in lubricant.

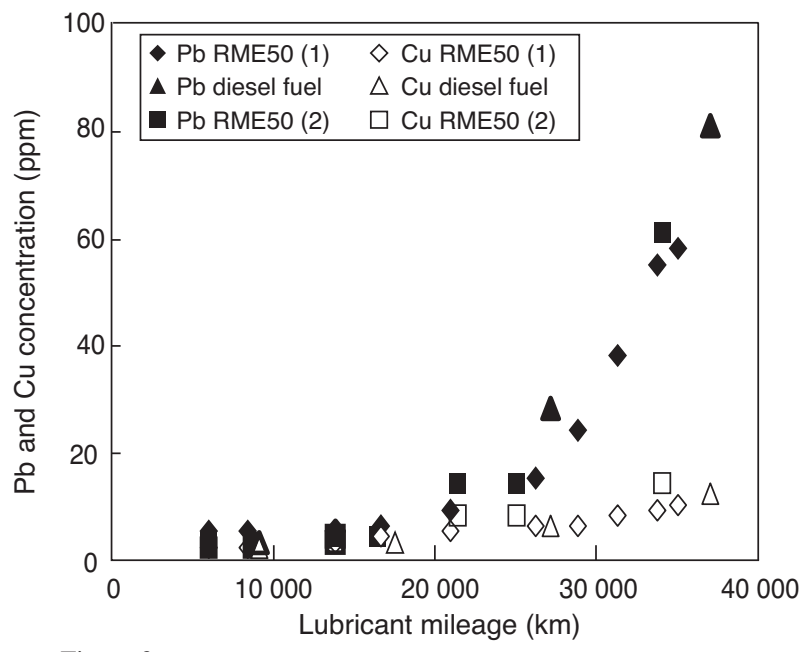

Figure 3

Lead and copper evolution in lubricant. 
not always detectable. Antifreeze was detected occasionally on vehicles $8, \mathrm{~T} 8$ and $\mathrm{T} 9$, and explained by coolant leakages of the water pump. For these vehicles, a high percentage of copper and lead was observed (Table 4), but contents went back to normal values later after repairing.

\subsection{Engines Expert Assessment}

The engines of vehicle pairs 2, 3, 4, 5 and 9 were disassembled and examined: wear and deposits were assessed according to CEC M-02-A-78 rating method.

Vehicles 2 and $\mathrm{T} 2$ were assessed at a driving mileage of about $200000 \mathrm{~km}$. No difference was found between the two engines, and the vehicles were reincorporated into the experiment after reassembly.

Vehicles 4, T4, 5 and T5 were assessed in 1997 in the presence of three experts at respectively $252774 \mathrm{~km}$, $238884 \mathrm{~km}, 461613 \mathrm{~km}$ and $433233 \mathrm{~km}$ mileages.

There was little difference observed between vehicle 4 and $\mathrm{T} 4$. The rings of the reference vehicle running on diesel fuel showed a more significant wear, which however was not corroborated by lubricant analyses as no significant variation in metals contents was observed.

The engines of vehicles 5 and T5 had been assessed prior to the experiment, the two vehicles having run on diesel fuel. A marked wear of piston rings, cams and tappets of inlet valve had been notified. So the importance of wear was confirmed at the last assessment for both engines.

At $461613 \mathrm{~km}$ mileage, vehicle 5 engine liners showed a notable polishing effect.

T5 engine showed an abnormal bore polishing and excessive piston rings wear at $433233 \mathrm{~km}$ mileage. On the other hand, analyses (Table 4 and Fig. 1) showed that the lubricant viscosity was particularly high and iron contents are higher than those of vehicle 5 . The the lubricant consumption was important. The source of this problem could not be determined but the experts concluded that the difference of wear between the two engines was not due to a positive effect of RME in fuel.

Later on, expert assessments were carried out on engines with mileage exceeding $500000 \mathrm{~km}$.

In year 2000, vehicles 3 and T3 were assessed at $664160 \mathrm{~km}$ mileage and $658692 \mathrm{~km}$ respectively. Vehicle 3 had run on RME50 over 495000 km mileage.

One piston of vehicle 3 showed scuffing marks on the skirt and the second ring land. The results of iron and aluminium content analyses in the lubricant did not make it possible to determine the time when this event occurred. This vehicle did not show any abnormal consumption (Table 3), the viscosity of the lubricant (Table 4) was normal. The expert discarded a fuel effect. No problem had been mentioned all over the years for this vehicle contrary to reference vehicle $\mathrm{T} 3$ whose bearings had been replaced at about $500000 \mathrm{~km}$ due to wear.

Vehicles 9 and T9 were assessed in 2005 respectively at 538868 and $530792 \mathrm{~km}$. Globally, the difference between the two vehicles is small. The ratings of both engines were good. The pink wear marks found on the reference vehicle's bearings were greater than those found on the vehicle running on RME50. They are explained by a leak of coolant into the oil and corroborated with copper content (Table 4). The deposits in piston grooves were more significant for the vehicle running on diesel fuel.

Contrary to the expectation that RME fuel would have produced deposits, inner parts of all the engines were clean, with clean crankcases and clean piston grooves. This was the case even for engines where the lubricant showed a marked viscosity fall.

All vehicles running on RME50 fuel showed white spots on piston and cylinder heads but these deposits were small and with no adverse effect. They are due to the very low alkali content of RME.

\subsection{Fuel and Injection Systems}

No tank (bare aluminium or bare steel) was subject to corrosion.

Injection systems of vehicle pairs 5 and 3 were checked using Bosch-approved equipment.

For vehicles 5 and T5, the hydraulic section of injection pumps was in perfect condition with no corrosion, nor defects of pistons, valves and springs of both engines. The deposits inside injector nozzles, and the changes of needle lifts were considered as normal.

For vehicles 3 and T3, the expert considered that pumps wear was normal. The difference in the average flow rates of both pumps was below $1 \%$, thus totally negligible. The discrepancy among the 6 cylinders of each pump was negligible for both engines.

\section{TESTS ON LIGHT VEHICLES}

\subsection{Vehicles Equipped with Prechamber Engines}

The first two-year experimental phase launched in February 1993 involved three pairs of cars, Renault R21D, Renault R19D, Renault Safrane 2.1 TUD, and two pairs of small utility vehicles Citroen C25D. All vehicles were equipped with prechamber engines.

No problem resulted from the use of RME. Oil change intervals, of $10000 \mathrm{~km}$ for utility vehicles and $7500 \mathrm{~km}$ for cars, were too small for dilution to occur, especially in the case of indirect injection engines. The maximum mileage of two of these vehicles using RME50 fuel was $80000 \mathrm{~km}$. 


\subsection{Vehicles with Common Rail and DPF}

A new test was launched in October 2001 for a three-year period, with four vehicles equipped with both 'common rail' injection systems and DPF: two Peugeot 406 (VL1 and VLT1) and two Citroën C5 (VL2 and VLT2), each of them including a vehicle running on RME50 and a reference vehicle.

The exhaust system of these four vehicles had an oxidation catalyst and a silicon carbide DPF. The soot oxidation catalyst is a fuel born catalyst automatically poured into the fuel tank at each fill-up by means of a system delivering a calculated amount of cerium additive from an auxiliary tank which is itself filled every $80000 \mathrm{~km}$.

\subsection{Behaviour of Vehicles Equipped with Common Rail}

No problem was reported for the RME50 car Peugeot 406 all over the three years.

The Electro-Diesel Company, representative of Bosch in Reims, reported a defective tightening of an injector involving a gas leak between the cylinder head and the injector at $45774 \mathrm{~km}$ mileage on the C5 car running on RME50. As a result, the injector was changed. Breakdowns on road also occurred at $54000 \mathrm{~km}$, due to the clogging of the fuel filter caused by a fatty deposit of low thickness. This deposit was submitted for analysis to ITERG (Institut des Corps Gras), which reported $20 \%$ contents of ashes, but no polymers originating from RME or of glycerol. No other incident has been reported with this vehicle.

The turbocharger of the C5 reference vehicle using diesel fuel was replaced following a breakdown in 2004.

Accumulated mileage at the end of the experiment is reported with average annual consumption on Table 5.

TABLE 5

Mileage and consumption of light vehicles

\begin{tabular}{c|c|c|c|c}
\hline & & \multicolumn{3}{|c}{ Mean consumption $(1 / 100 \mathrm{~km})$} \\
\hline & Final mileage (2005) & 2002 & 2003 & 2004 \\
\hline VL1 & 231000 & 7.18 & 7.04 & 6.75 \\
\hline VLT1 & 109000 & 7.58 & 6.85 & 6.63 \\
\hline VL2 & 191000 & 7.49 & 7.26 & 7.37 \\
\hline VLT2 & 135000 & 7.76 & 7.07 & 6.90 \\
\hline
\end{tabular}

Injections were checked at the beginning and at $80000 \mathrm{~km}$ mileage, using Bosch KTS 550 equipment connected to the vehicle computer. Checks involved pressure and injection flow rate measurements on idle and $3000 \mathrm{rpm}$. No defect was observed on all four vehicles. The injection system of 406 and C5 vehicles using RME50 was completely removed and replaced, respectively at $167801 \mathrm{~km}$ and $149518 \mathrm{~km}$, and the used systems subject to expert assessment. No defect was reported.

Variations of mean annual consumptions (Table 5) are due to driving differences, but the global average values are consistent with LHV differences.

Pollutants and particulate size were measured by IFP at 20000 and at $80000 \mathrm{~km}$ mileage. Pollutants were also measured for the Peugeot 406 car at $158819 \mathrm{~km}$. It was concluded that RME had no effect on DPF. It was even observed that RME50 could lengthen interval time between DPF regenerations.

\subsection{Lubricant Analyses}

The vehicles used 5W30 lubricants supplied by the Total company:

- ACEA 2002 for 406 cars;

- ACEA 98 for C5 cars.

The first oil changes was set at about $6000 \mathrm{~km}$ after run-in and all the other oil change intervals were set to $20000 \mathrm{~km}$.

Tables 6 and 7 show mean values of the lubricant analysis calculated on the first five oil changes after run-in.

TABLE 6

\begin{tabular}{c|c|c|c|c|c|c|c|c}
\multicolumn{10}{c}{ Mean values of metal contents (ppm) } \\
\hline & $\mathrm{Fe}$ & $\mathrm{Pb}$ & $\mathrm{Cu}$ & $\mathrm{Sn}$ & $\mathrm{Cr}$ & $\mathrm{Al}$ & $\mathrm{Ni}$ & $\mathrm{Si}$ \\
\hline VL1 & 122 & 18 & 8 & 0.4 & 5 & 10 & 1.6 & 11 \\
\hline VLT1 & 91 & 10 & 6 & 0.6 & 5 & 11 & 0.8 & 20 \\
\hline VL2 & 90 & 41 & 11 & 0.2 & 3 & 10 & 2.8 & 12 \\
\hline VLT2 & 121 & 12 & 9 & 1.0 & 6 & 15 & 2.0 & 18 \\
\hline
\end{tabular}

TABLE 7

Mean values of lubricant analysis

\begin{tabular}{c|c|c|c|c}
\hline & $\begin{array}{c}\text { Soot } \\
\%\end{array}$ & $\begin{array}{c}\mathrm{Vis}\left(40^{\circ} \mathrm{C}\right) \\
\mathrm{cSt}\end{array}$ & $\begin{array}{c}\mathrm{BN} \\
\mathrm{mg} \mathrm{KOH} / \mathrm{g}\end{array}$ & $\begin{array}{c}\mathrm{AN} \\
\mathrm{mg} \mathrm{KOH} / \mathrm{g}\end{array}$ \\
\hline $\mathrm{VL} 1$ & 0.32 & 43.8 & 7.9 & 4.8 \\
\hline VLT1 & 0.26 & 47.4 & 7.1 & 5.2 \\
\hline VL2 & 0.24 & 46.2 & 8.0 & 4.8 \\
\hline VLT2 & 0.34 & 58.5 & 9.1 & 4.9
\end{tabular}

The iron content is neither related to the fuel nor silicon content: it is smaller for the 406 reference vehicle but smaller for the C5 running on RME50. On Table 7, it seems correlated to soot contents, but in fact this is not the case when examining all the individual data.

Basicity and acidity numbers are similar for all four vehicles. 
Lubricant viscosity is higher for VLT2: dilution is mentioned on the analysis bulletins for VL1, VLT1 and VL2 but not for VLT2.

\section{CONCLUSION}

An experiment in the use of a fuel mixture of RME was carried out at the agricultural cooperative Champagne Céréales over the period 1993-2005. The rate of 50\% mixture selected in 1993 was maintained to ensure consistent experimental conditions, although the mixture rate generally used in common practice in France is $30 \%$.

No negative effect of the use of RME50 in 5 heavy trucks was reported in expert assessments. When incidents were reported, they were not related to the kind of fuel. Moreover, the reference vehicles were affected more frequently.

The dilution of the lubricant was increased by the use of RME50, but no wear increase and no deposits in the piston rings or the crankcases were observed.

It was assumed that the reduction of wear observed with the use of RME50 on certain heavy trucks could be explained by the fact that RME reduces the level of smoke emissions, which in turn reduces the contents of soot in the lubricant.

The most recent cars ran over a significant mileage using RME50 with no injection problem reported.

This twelve-year experiment has shown that a $50 \%$ RME fuel mixture was fully accepted by heavy trucks and cars equipped with a common rail injection system and particulate filters. The effect of RME on consumption varied, on the whole, according to the LHV variation.

\section{ACKNOWLEDGEMENTS}

This experiment was made possible by the financial support of Ademe, Onidol, Total company and the Cooperative Champagne Céréales.
All the expert assessments were carried out by Gérard Durante of the Institut Français du Pétrole. The injection systems were controlled by Marc Lefevre of the Electrodiesel Company, representative of Bosch at Reims. The lubricant analyses were carried out by the Diagoparc Company.

\section{GLOSSARY}

$\begin{array}{ll}R M E & \text { Rapeseed Oil Methyl Ester } \\ D P F & \text { Diesel Particulate Filter } \\ \text { LHV } & \text { Lower Heating Value } \\ \text { ITERG } & \text { Institut des Corps Gras } \\ \text { IFP } & \text { Institut Français du Pétrole }\end{array}$

\section{REFERENCES}

1 Jamet, J.-P. (1993) Le diester, les enjeux du Diesel vert. Editions de l'environnement, Paris, ISBN 2.908620-09-X.

2 Gateau, P., Guibet, J.-C., Hillion, G. and Stern, R. (1985) Utilisation des huiles végétales et de leurs produits de transestérification comme carburants Diesel. Oil Gas Sci. Technol, 40, 509-528.

3 Staat, F. (1992) The Effects of Rapeseed Methyl Esters on Diesel Engine Pollution - A Review. 25th ISATA, Florence, Italy, June 1-5, 357-364.

4 Staat, F. and Gateau, P. (1995) The Effects of Rapeseed Oil Methyl Ester on Diesel Engine Performance, Exhaust Emissions and Long-Term Behavior - A Summary of Three Years of Experimentation. SAE 950053.

5 Ballerini, D. and Hillion, G. (2002) Méthanolyse des huiles végétales. Actual. Chimique, 258-259, 64-69.

6 Bournay, L., Chodorge, J.L., Delfort, B., Forestière, A. and Hillion, G. (2002) New continuous process of biodiesel production. Proceedings of the 2002 European Conference on Biomass for Energy, Industry and Climate Protection, Amsterdam, Netherlands, 17-21 June 2002.

7 Mittelbach, M. and Remschmidt, C. (2004) Biodiesel: the comprehensive handbook. Martin Mittelbach Ed.

8 Reid, R.C., Prausnitz, J.M. and Sherwood, T.K. (1977) Liquid-Mixture Viscosity in The Properties of Gases and Liquids. McGraw-Hill, New York.

Final manuscript received in August 2006 